\title{
Study on Physico-Chemical Parameters in Different Mangrove Regions, Southeast Coast of India
}

\author{
Srilatha G*, Varadharajan D, Chamundeeswari K and Mayavu P \\ CAS in Marine Biology, Faculty of Marine Sciences, Annamalai University, Parangipettai, Tamil Nadu, India
}

\begin{abstract}
A study was undertaken to determine the physico-chemical parameters of water in different mangrove regions of Indian coast. Flora and faunas are living in that regions and it can provide wild life places for living and foraging. Physicochemical parameters are influence the species diversity, pattern of diversity, spawning, breeding and metabolic activities. The temperature, $\mathrm{pH}$, salinity, dissolved oxygen and nutrients are the major master factors of coastal water ecosystem. These parameters are occurring optimum level for the survival of species and poor water quality can influence the species activities and patterns of behavior. However, the base line physico- chemical data is toward the further study of ecological and conservation of economically and they are living species diversity patterns.
\end{abstract}

Keywords: Physico-chemical; Parameters; Influence; Organisms; Mangrove region

\section{Introduction}

The physico-chemical characteristics are said to play a significant role in the distribution of organisms such as reproduction, feeding etc. Various physico-chemical and biological processes in the mangals make it a habitat for vast array of organisms, leading to rich biodiversity [1] but seasonal variation and anthropogenic pressures bring about a lot of changes in physical-chemical characteristics, which affect the biotic elements of the mangals system. The most important variables which influence the mangrove are temperature, salinity, tides, rainfall and wind. Survival and development of regeneration and recruitment classes depend on salinity and solar radiation [2]. Temperature and salinity determine the species composition, distribution and zonation. Tidal amplitude with topography structure regulates the landward extension of the mangroves. Many studies related to hydro biological parameters were carried out in Indian coastal waters. Of which, Menon et al. [3] studied the hydrobiology of the Cochin backwaters, south west coast of India. The physico chemical characteristics of Pichavaram mangroves, south east coast of India by Rajendran [4] and Kathiresan [2,5]. Information on various physico-chemical and biological process, which controlling the prevailing environmental conditions of the region, will eventually helps to evaluate the ecological changes. Studies on hydrograhy of backwaters and mangroves of east coast of India [6] are limited when compared to the mangroves of west coast. Sundarbans [7], Bitherkanika [7,8], Krishna and Godawari delta [9] in east coast, Pitchavaram [10,11]. Physico-chemical parameters are most serious problems of aquatic organisms. It can affect the species diversity, presence and absence of species and pattern of distribution such as directly or indirectly and totally change the species behavior of inhabitants regions. The aim of the present study was to determine whether the physical and chemical parameters of monthly variability in different coastal environment.

\section{Materials and Methods}

Surface water samples were collected at monthly interval at two different stations, Station I- Muthupettai and Station II-Pointcalimere for a period of one year from October 2006 to September 2007 to analyze various physico-chemical parameters (Figure 1). Rainfall data for the study area was collected from the meteorological unit. The atmospheric and water temperature were measured using a digital centigrade thermometer. Salinity was estimated with the help of a hand refractrometer (ERMA, Japan) and $\mathrm{pH}$ was measured using an ELICO Grip $\mathrm{pH}$ meter. Dissolved oxygen was estimated by the modified Winkler's method [12].

For the analysis of nutrients, surface water samples were collected in clean polythene bottles and kept immediately in an icebox and transported to the laboratory. The water samples were than filtered using a millipore filtering system and analyzed for dissolved inorganic phosphate, total phosphorus, total Nitrogen, nitrate, nitrite, ammonia and reactive silicate by adopting standard procedure of [12].

\section{Results}

\section{Rainfall}

Rainfall in the southeast coast of India is largely influenced by the northeast monsoon, while, the southwest monsoon serves the coast.

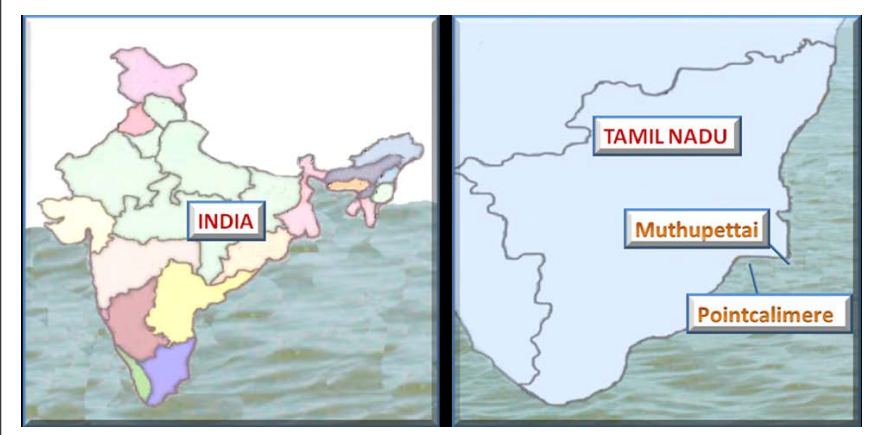

Figure 1: Map showing the study area.

*Corresponding author: G. Srilatha, Faculty of Marine Sciences, Centre of Advanced Study in Marine Biology, Annamalai University, Parangipettai-608 502, Tamil Nadu, India, Tel: 04144-243223; Fax: 04144-243553; E-mail: srigovisaro@gmail.com

Received June 17, 2013; Accepted July 21, 2013; Published July 23, 2013

Citation: Srilatha G, Varadharajan D, Chamundeeswari K, Mayavu P (2013) Study on Physico-Chemical Parameters in Different Mangrove Regions, Southeast Coast of India. J Environ Anal Toxicol 3: 182. doi:10.4172/2161-0525.1000182

Copyright: $\odot 2013$ Srilatha G, et al. This is an open-access article distributed under the terms of the Creative Commons Attribution License, which permits unrestricted use, distribution, and reproduction in any medium, provided the original author and source are credited. 
Citation: Srilatha G, Varadharajan D, Chamundeeswari K, Mayavu P (2013) Study on Physico-Chemical Parameters in Different Mangrove Regions, Southeast Coast of India. J Environ Anal Toxicol 3: 182. doi:10.4172/2161-0525.1000182

Page 2 of 8

Based on the cyclic phenomena of meteorological events, four seasons are broadly indicated in a calendar year they are: (1). Post monsoon (January to March) (2) Summer (April to June) (3) Pre monsoon (July to September) and (4) Monsoon (October to December).

The Rainfall at Point Calimere varied from $15.8 \mathrm{~mm}$ to $747 \mathrm{~mm}$ (Figure 2). Maximum (747 mm) was recorded during monsoon (Nov. 2006) and minimum (15.8 $\mathrm{mm}$ ) was recorded during summer (Jun. 2007). In Muthupettai, it was varied between $302 \mathrm{~mm}$ and $30.2 \mathrm{~mm}$ (Figure 2). Maximum (302 mm) was recorded during monsoon (Oct. 2006) and in minimum $(30.2 \mathrm{~mm})$ was recorded during post- monsoon (Feb. 2007).

\section{Atmosphere Temperature}

The Atmosphere temperature at Point Calimere varied from $25.0^{\circ} \mathrm{C}$ to $29.9^{\circ} \mathrm{C}$ (Figure 3) Maximum $\left(29.9^{\circ} \mathrm{C}\right.$ ) was recorded during post monsoon (Mar. 2007) and in minimum $\left(25.0^{\circ} \mathrm{C}\right)$ was observed during pre-monsoon (Dec. 2006). At Muthupettai, it was ranged from 21 to 32.8 (Figure 3). Maximum $\left(32.8^{\circ} \mathrm{C}\right)$ was recorded during summer (May 2007) and minimum $\left(21.0^{\circ} \mathrm{C}\right)$ was recorded during monsoon (Dec. 2007). The two-ways ANOVA showed non-significant variations between the seasons and stations (Table 1 ). The dissolved oxygen values between the two stations are positively correlated $(\mathrm{r}=0.344 ; \mathrm{p}>0.10)$.

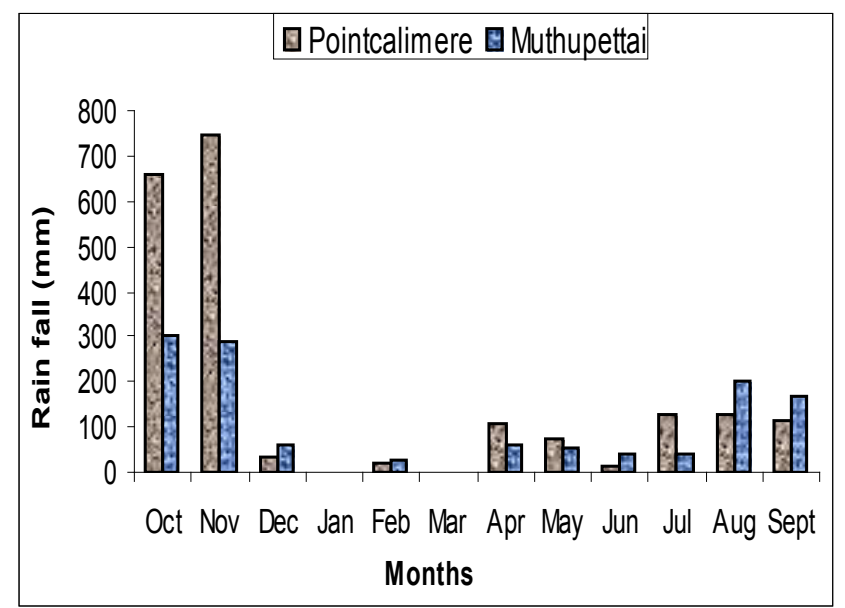

Figure 2: Monthly variations in Rainfall.

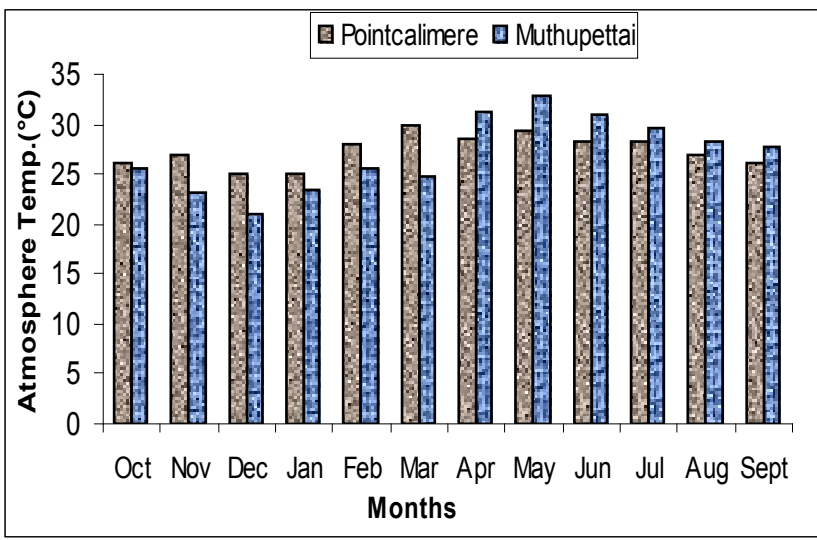

Figure 3: Monthly variations in Atmosphere temperature.

\begin{tabular}{|c|c|c|c|c|c|c|}
\hline Source of Variation & SS & df & MS & F & F crit & P-value \\
\hline Seasons & 0.8067 & 1 & 0.8067 & 0.1833 & 4.8443 & NS \\
\hline Stations & 129.0750 & 11 & 11.7341 & 2.6667 & 2.8179 & NS \\
\hline Error & 48.4033 & 11 & 4.4003 & & & \\
\hline Total & 178.2850 & 23 & & & & \\
\hline \multicolumn{7}{|l}{ Table 1: Two-way ANOVA between seasons and station. }
\end{tabular}

\section{Water temperature}

The water temperature at Point Calimere varied from $26.0^{\circ} \mathrm{C}$ to $30.2^{\circ} \mathrm{C}$ (Figure 4 ). Maximum $\left(30.2^{\circ} \mathrm{C}\right)$ was recorded during monsoon (Nov. 2006) and in the minimum $\left(26.0^{\circ} \mathrm{C}\right)$ was observed in post monsoon (Jan. 2007). The water temperature at Muthupettai varied from $23.0^{\circ} \mathrm{C}$ to $30.0^{\circ} \mathrm{C}$ (Figure 4 ). Maximum $\left(30.0^{\circ} \mathrm{C}\right.$ ) was recorded during summer (May 2007) and in the minimum $\left(23.0^{\circ} \mathrm{C}\right)$ was observed during monsoon (Dec. 2006). The two-ways ANOVA showed non-significant variations between the seasons and stations (Table 2). The dissolved oxygen values between the two stations are positively correlated $(\mathrm{r}=0.344 ; \mathrm{p}<0.0 .12)$.

\section{Salinity}

The values of salinity varied from $24.0 \mathrm{ppt}$ to $34.0 \mathrm{ppt}$ (Figure 5). Minimum (24.0 ppt) was recorded during monsoon (Dec. 2006) and the maximum (34.0 ppt) was recorded during pre-monsoon (Aug. 2007) in Point Calimere. The Muthupettai, it was varied from $24.0 \mathrm{ppt}$ to $34 \mathrm{ppt}$ (Figure 5) Maximum (34ppt) was recorded during summer (May 2006) and minimum (24) was recorded during Monsoon (Dec. 2006). The two ways ANOVA showed non-significant variations between the seasons and stations (Table 3 ). The dissolved oxygen values between the two stations are positively correlated $(r=0.926 ; \mathrm{p}>0.001)$.

\section{Water $\mathbf{p H}$}

In Point Calimere, it was varied from 7.4 to 8.2 (Figure 6). Maximum (8.2) was recorded during post monsoon (Feb. 2007) and minimum (7.4) was recorded during monsoon (Nov.2006). The Muthupettai varied from 7.4 to 8.3 (Figure 6). Maximum (8.3) was recorded in summer (May 2007) and minimum (7.4) was recorded during monsoon (Nov. 2006). The two way ANOVA showed significant variations between the seasons $(\mathrm{p}<0.05)$ and stations $(\mathrm{p}<0.05)$ in $($ Table 4 ). The dissolved oxygen values between the two stations are positively correlated $(r=0.982 ; \mathrm{p}>0.001)$.

\section{Dissolved Oxygen}

At Point Calimere, it was varied from $3.92 \mathrm{mg} / \mathrm{l}$ to $5.22 \mathrm{mg} / \mathrm{l}$ (Figure 7). The maximum $(5.22 \mathrm{mg} / \mathrm{L})$ was recorded in post monsoon (Mar. 2007) and the minimum (3.92 $\mathrm{mg} / \mathrm{L})$ was recorded during monsoon (Oct. 2006). In Muthupettai, the dissolved oxygen was varied from 3.97 $\mathrm{mg} / \mathrm{l}$ to $5.33 \mathrm{mg} / \mathrm{l}$ (Figure 7). The maximum $(5.33 \mathrm{mg} / \mathrm{l})$ was recorded during summer (May 2007) and minimum $(3.97 \mathrm{mg} / \mathrm{l})$ was recorded during Monsoon (Nov. 2006). The two-way ANOVA showed nonsignificant variations between the seasons and significant variations between stations $(p<0.05)$ in (Table 5$)$. The dissolved oxygen values between the two stations are positively correlated $(r=0.916 ; p>0.001)$.

\section{Turbidity}

The Turbidity at Point Calimere varied from 43.0 NTU to 260.0 NTU (Figure 8). Maximum (260.0 NTU) was recorded during premonsoon (July 2006) and minimum (43.0 NTU) was recorded during summer (May 2007). At Muthupettai varied from 40.0 NTU to 792 NTU (Figure 8). The maximum (792 NTU) was recorded during summer (May 2006) and in the minimum (40.0 NTU) was recorded 
Citation: Srilatha G, Varadharajan D, Chamundeeswari K, Mayavu P (2013) Study on Physico-Chemical Parameters in Different Mangrove Regions, Southeast Coast of India. J Environ Anal Toxicol 3: 182. doi:10.4172/2161-0525.1000182

Page 3 of 8

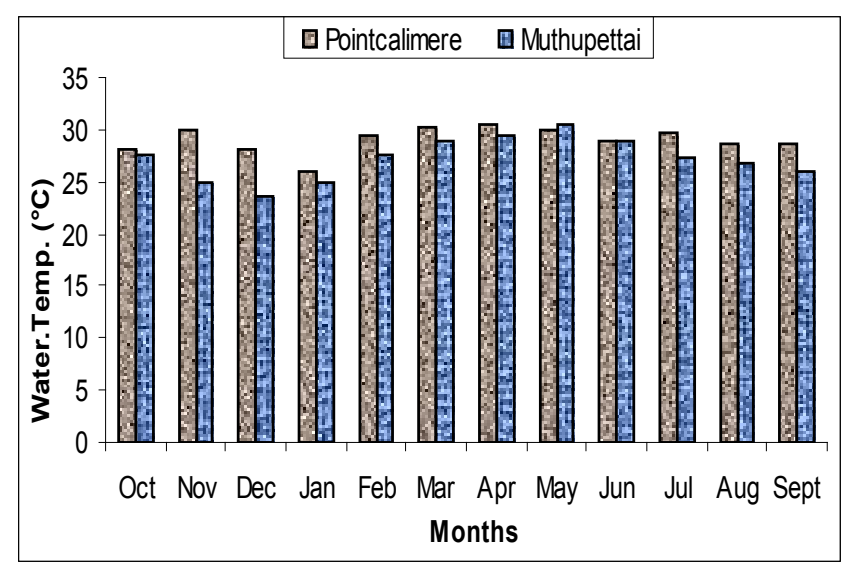

Figure 4: Monthly variations in water temperature.

\begin{tabular}{|c|c|c|c|c|c|c|}
\hline Source of Variation & SS & df & MS & F & F crit & P-value \\
\hline Seasons & 20.7204 & 1 & 20.7204 & 15.7683 & 4.8443 & NS \\
\hline Stations & 48.7346 & 11 & 4.4304 & 3.3716 & 2.8179 & NS \\
\hline Error & 14.4546 & 11 & 1.3141 & & & \\
\hline Total & 83.9096 & 23 & & & & \\
\hline
\end{tabular}

Table 2: The two-way ANOVA between stations and seasons.

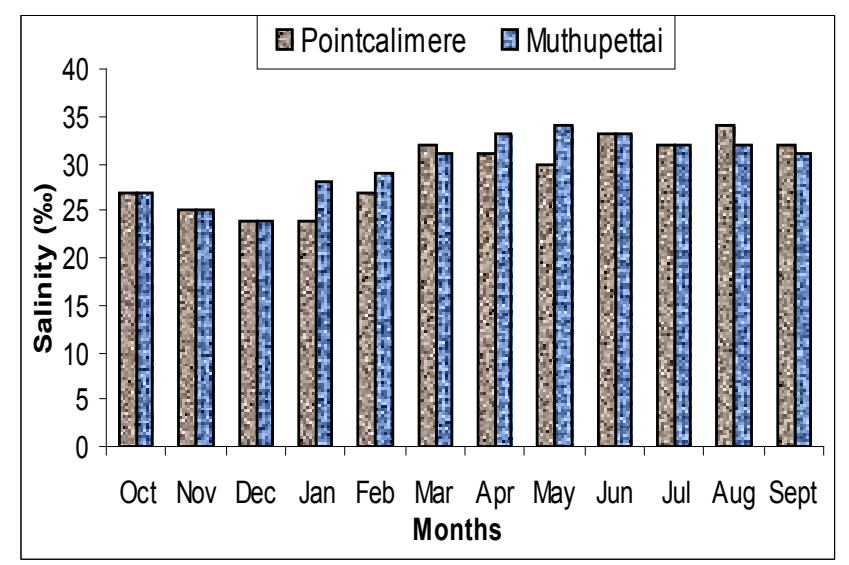

Figure 5: Monthly variations in salinity.

\begin{tabular}{|c|c|c|c|c|c|c|}
\hline Source of Variation & SS & df & MS & F & F crit & P-value \\
\hline Seasons & 3.3750 & 1 & 3.3750 & 1.8447 & 4.8443 & NS \\
\hline Stations & 250.4583 & 11 & 22.7689 & 12.4451 & 2.8179 & NS \\
\hline Error & 20.1250 & 11 & 1.8295 & & & \\
\hline Total & 273.9583 & 23 & & & & \\
\hline
\end{tabular}

Table 3: The two-way ANOVA between stations and seasons.

during post monsoon (Jan.2007). The two-ways ANOVA showed non-significant variations between the seasons and stations (Table 6). The dissolved oxygen values between the two stations are positively correlated $(r=-0.048 ; p>0.001)$.

\section{Total suspended solids}

The total suspended solids at Point Calimere varied from $82.0 \mathrm{mg} / \mathrm{l}$ to $522.0 \mathrm{mg} / \mathrm{l}$ (Figure 9). Maximum $(522.0 \mathrm{mg} / \mathrm{l})$ was recorded during pre-monsoon (July 2007). Minimum $(82.0 \mathrm{mg} / \mathrm{l})$ was recorded during summer (May 2007). In Muthupettai, it was varied from $82.1 \mathrm{mg} / \mathrm{l}$ to
$1506.4 \mathrm{mg} / \mathrm{l}$ (Figure 9). The maximum (1506.4 mg/l) was recorded during summer (May 2007) and the minimum (82.1 mg/l) was observed during post-monsoon (Jan. 2007). The two-ways ANOVA showed non-significant variations between the seasons and stations (Table 7). The dissolved oxygen values between the two stations are positively correlated $(\mathrm{r}=-0.115 ; \mathrm{p}>0.001)$.

\section{Water nutrients}

Inorganic phosphate: The value of inorganic phosphate was ranged

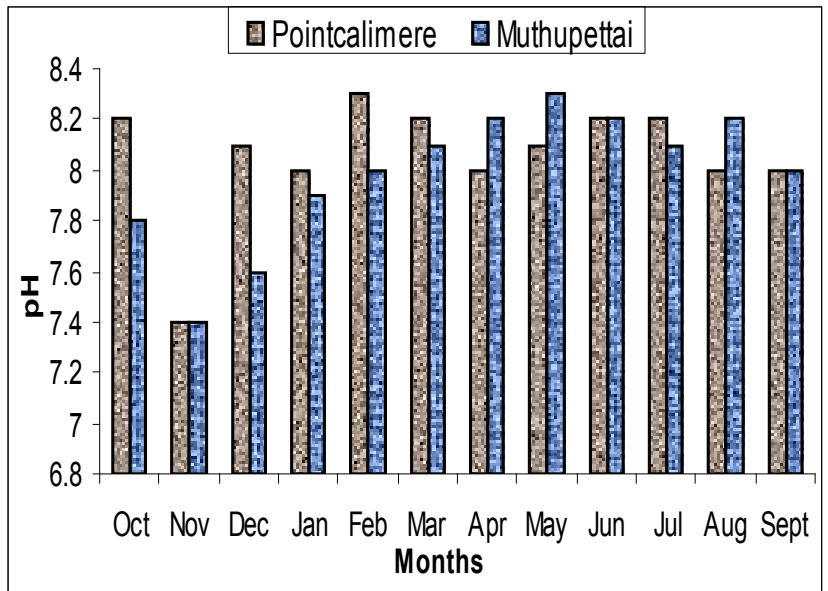

Figure 6: Monthly variations in Water $\mathrm{pH}$.

\begin{tabular}{|c|c|c|c|c|c|c|}
\hline Source of Variation & SS & df & MS & F & F crit & P-value \\
\hline Seasons & 0.0338 & 1 & 0.0338 & 1.2747 & 4.8443 & $<0.05$ \\
\hline Stations & 1.0946 & 11 & 0.0995 & 3.7582 & 2.8179 & $<0.05$ \\
\hline Error & 0.2913 & 11 & 0.0265 & & & \\
\hline Total & 1.4196 & 23 & & & & \\
\hline
\end{tabular}

Table 4: The two-way ANOVA between stations and seasons.

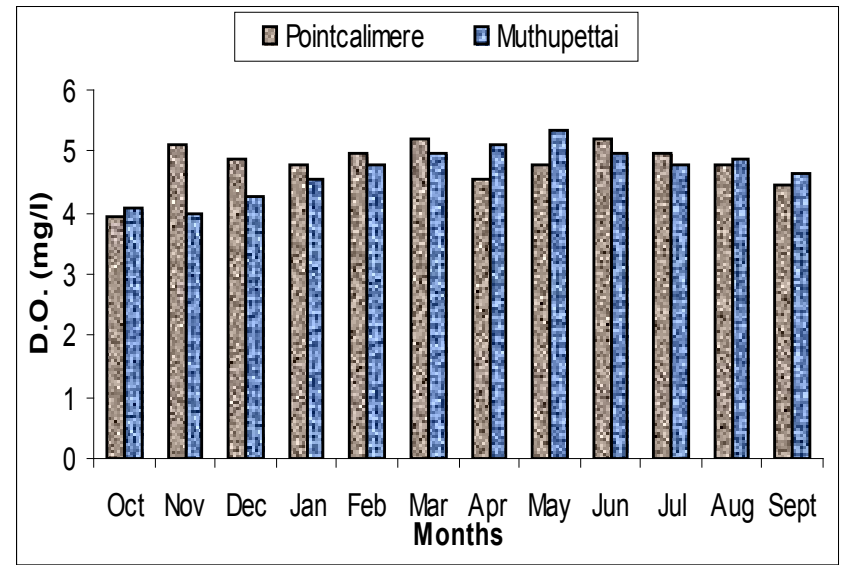

Figure 7: Monthly variations in dissolved oxygen.

\begin{tabular}{|c|c|c|c|c|c|c|}
\hline Source of Variation & SS & df & MS & F & F crit & P-value \\
\hline Seasons & 0.0610 & 1 & 0.0610 & 0.5321 & 4.8443 & NS \\
\hline Stations & 2.1183 & 11 & 0.1926 & 1.6797 & 2.8179 & $<0.05$ \\
\hline Error & 1.2611 & 11 & 0.1146 & & & \\
\hline Total & 3.4405 & 23 & & & & \\
\hline
\end{tabular}

Table 5: Two-way ANOVA between seasons and stations. 
Citation: Srilatha G, Varadharajan D, Chamundeeswari K, Mayavu P (2013) Study on Physico-Chemical Parameters in Different Mangrove Regions, Southeast Coast of India. J Environ Anal Toxicol 3: 182. doi:10.4172/2161-0525.1000182

Page 4 of 8

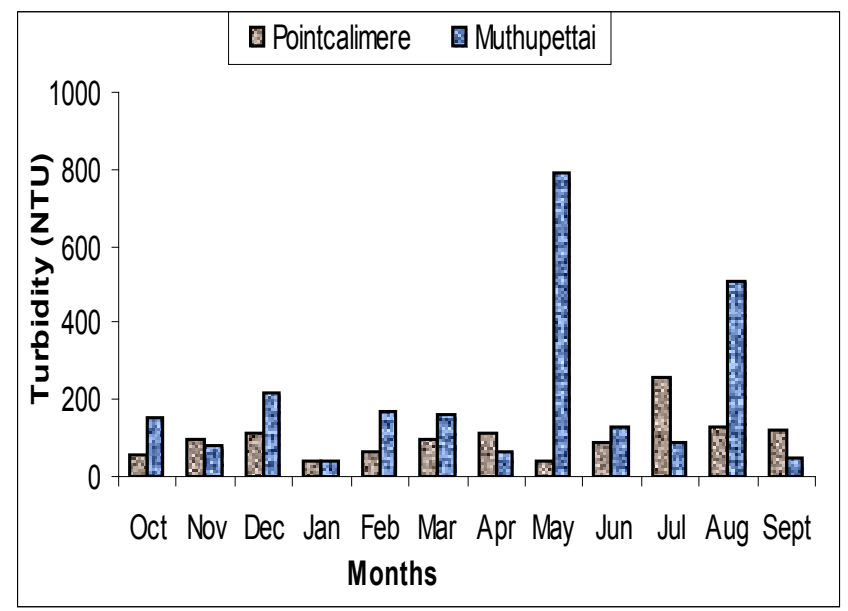

Figure 8: Monthly variations in Turbidity.

\begin{tabular}{|c|c|c|c|c|c|c|}
\hline Source of Variation & SS & df & MS & F & F crit & P-value \\
\hline Seasons & 65417.04 & 1 & 65417.0417 & 2.2058 & 4.8443 & NS \\
\hline Stations & 258667.45 & 11 & 23515.2235 & 0.7929 & 2.8179 & NS \\
\hline Error & 326221.45 & 11 & 29656.4962 & & & \\
\hline Total & 650305.95 & 23 & & & & \\
\hline
\end{tabular}

Table 6: The two-way ANOVA between the stations and seasons.

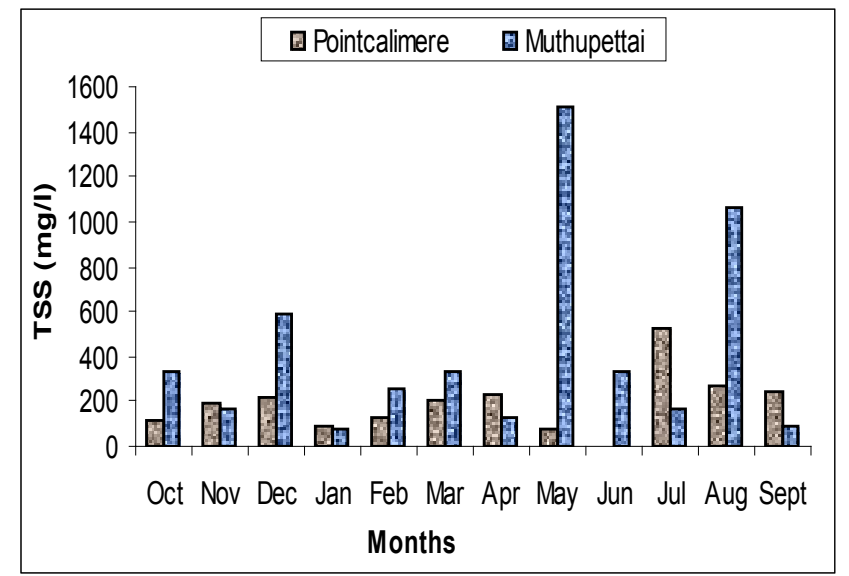

Figure 9: Monthly variations in total suspended solids.

\begin{tabular}{|c|c|c|c|c|c|c|}
\hline Source of Variation & SS & df & MS & F & F crit & P-value \\
\hline Seasons & 613984.0704 & 1 & 613984.0704 & 5.9564 & 4.8443 & NS \\
\hline Stations & 1009353.2546 & 11 & 91759.3868 & 0.8902 & 2.8179 & NS \\
\hline Error & 1133883.0546 & 11 & 103080.2777 & & & \\
\hline Total & 2757220.3796 & 23 & & & & \\
\hline
\end{tabular}

Table 7: The two-way ANOVA between the stations and seasons.

from $0.550 \mu \mathrm{mol} / \mathrm{l}$ to $0.984 \mu \mathrm{mol} / \mathrm{l}$ (Figure 10). Maximum $(0.984 \mu \mathrm{mol} / \mathrm{l}$ ) was recorded during post monsoon (Mar. 2007) and in the minimum $(0.550 \mu \mathrm{mol} / \mathrm{l})$ was observed in monsoon (Nov. 2006). The inorganic phosphate at Muthupettai varied from $0.470 \mu \mathrm{mol} / \mathrm{l}$ to $2.620 \mu \mathrm{mol} / \mathrm{l}$ (Figure 10). The maximum $(2.620 \mu \mathrm{mol} / \mathrm{l})$ was recorded during post monsoon (Dec. 2006) and in minimum $(0.470 \mu \mathrm{mol} / \mathrm{l})$ was observed in post monsoon (Jan. 2007). The two-way ANOVA showed significant variations between the seasons $(\mathrm{p}<0.05)$ and stations $(\mathrm{p}<0.05)($ Table
8). The dissolved oxygen values between the two stations are positively correlated $(\mathrm{r}=0.926116 ; \mathrm{p}>0.001)$.

Total phosphorus: The Total phosphorus at Point Calimere varied from $1.32 \mu \mathrm{mol} / \mathrm{l}$ to $2.893 \mu \mathrm{mol} / \mathrm{l}$ (Figure 11). Minimum $(1.32 \mu \mathrm{mol} / \mathrm{l})$ was recorded during post monsoon (Jan. 2007) and in maximum $(2.893 \mu \mathrm{mol} / \mathrm{l})$ was recorded during pre monsoon (September 2007). At Muthupettai, it was varied from $1.29 \mu \mathrm{mol} / \mathrm{l}$ to $3.425 \mu \mathrm{mol} / \mathrm{l}$ (Figure 11). The minimum $(1.29 \mu \mathrm{mol} / \mathrm{l})$ was recorded during summer (Jun 2007) and the maximum $(3.425 \mu \mathrm{mol} / \mathrm{l})$ was recorded during monsoon (Nov. 2006). The two-way ANOVA showed significant variations between the seasons $(p<0.05)$ and stations $(p<0.05)$ in $($ Table 9$)$. The dissolved oxygen values between the two stations are positively correlated $(\mathrm{r}=0.926116 ; \mathrm{p}>0.001)$.

Total Nitrogen: The Total nitrogen at Point Calimere varied from $5.123 \mu \mathrm{mol} / \mathrm{l}$ to $38.916 \mu \mathrm{mol} / \mathrm{l}$ (Figure 12$)$. Maximum $(38.916 \mu \mathrm{mol} / \mathrm{l})$

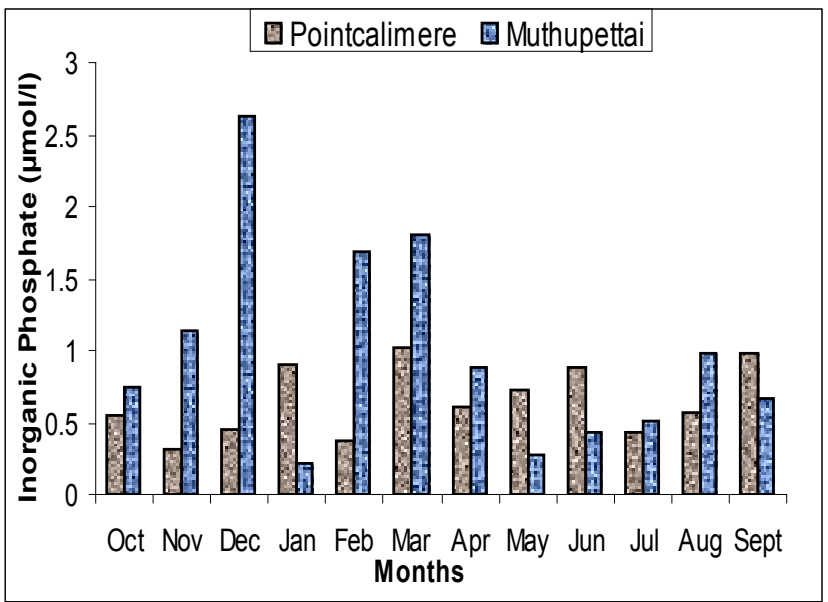

Figure 10: Monthly variations in inorganic phosphate.

\begin{tabular}{|c|c|c|c|c|c|c|}
\hline Source of Variation & SS & df & MS & F & F crit & P-value \\
\hline Seasons & 0.7259 & 1 & 0.7259 & 2.1181 & 4.8443 & $<0.05$ \\
\hline Stations & 2.5464 & 11 & 0.2315 & 0.6755 & 2.8179 & $<0.05$ \\
\hline Error & 3.7699 & 11 & 0.3427 & & & \\
\hline Total & 7.0423 & 23 & & & & \\
\hline
\end{tabular}

Table 8: The two-way ANOVA between the stations and seasons.

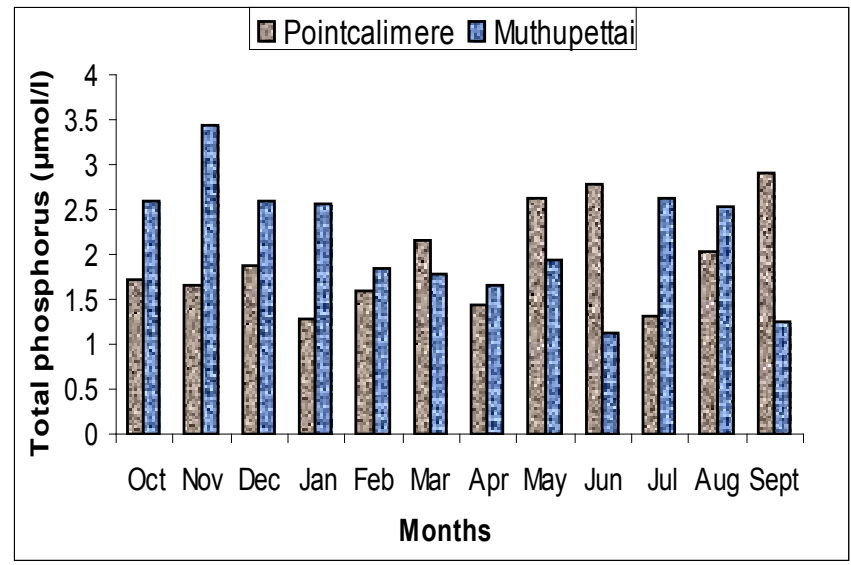

Figure 11: Monthly variations in Total phosphorus. 
Citation: Srilatha G, Varadharajan D, Chamundeeswari K, Mayavu P (2013) Study on Physico-Chemical Parameters in Different Mangrove Regions, Southeast Coast of India. J Environ Anal Toxicol 3: 182. doi:10.4172/2161-0525.1000182

was recorded during monsoon (Oct. 2006) and in minimum (5.123 $\mu \mathrm{mol} / \mathrm{l}$ ) was recorded during summer (May 2007). The total nitrogen at Muthupettai varied from $5.436 \mu \mathrm{mol} / \mathrm{l}$ to $37.382 \mu \mathrm{mol} / \mathrm{l}$ (Figure 12). Maximum (37.382 $\mu \mathrm{mol} / \mathrm{l})$ was recorded during monsoon (Oct. 2006). Minimum $(5.436 \mu \mathrm{mol} / \mathrm{l})$ was recorded during summer (May 2007). The two-way ANOVA showed non-significant variations between the seasons and stations (Table 10). The dissolved oxygen values between the two stations are positively correlated $(r=0.926116 ; \mathrm{p}>0.001)$.

Ammonia: The Ammonia at Point Calimere varied from 0.120 $\mu \mathrm{mol} / \mathrm{l}$ to $0.698 \mu \mathrm{mol} / \mathrm{l}$ (Figure 13 ). (Maximum $(0.698 \mu \mathrm{mol} / \mathrm{l})$ was recorded during monsoon (Dec. 2006). Minimum $(0.0 .120 \mu \mathrm{mol} / \mathrm{l})$ was recorded during summer (May 2007). At Muthupettai, it was varied from $0.030 \mu \mathrm{mol} / 1$ to $0.744 \mu \mathrm{mol} / \mathrm{l}$ (Figure 13). Maximum $(0.744$ $\mu \mathrm{mol} / \mathrm{l}$ ) was recorded during pre monsoon (Aug. 2007). Minimum $(0.030 \mu \mathrm{mol} / \mathrm{l})$ was recorded during post monsoon (Feb. 2007). The two-ways ANOVA showed non-significant variations between the seasons and stations (Table 11). The dissolved oxygen values between the two stations are positively correlated $(r=0.926116 ; p>0.001)$.

Nitrite: The nitrite at Point Calimere varied from $0.082 \mu \mathrm{mol} / 1$ to $1.957 \mu \mathrm{mol} / \mathrm{l}$ (Figure 14). Maximum $(1.957 \mu \mathrm{mol} / \mathrm{l})$ was recorded during pre monsoon (Sep. 2007) and minimum $(0.082 \mu \mathrm{mol} / \mathrm{l})$ was recorded during post monsoon (Feb.2007). At Muthupettai, it was varied from $0.060 \mu \mathrm{mol} / \mathrm{l}$ to $2.082 \mu \mathrm{mol} / \mathrm{l}$. Maximum $(2.082 \mu \mathrm{mol} / \mathrm{l})$ was recorded during monsoon (Nov. 2006) and minimum $(0.06 \mu \mathrm{mol} / \mathrm{l})$ was recorded during summer (May 2007). The two-way ANOVA showed significant variations between the seasons $(\mathrm{p}<0.05)$ and stations $(\mathrm{p}<0.05)$, (Table 12). The dissolved oxygen values between the two stations are positively correlated $(\mathrm{r}=0.926116 ; \mathrm{p}>0.001)$.

\begin{tabular}{|c|c|c|c|c|c|c|}
\hline Source of Variation & SS & df & MS & F & F crit & P-value \\
\hline Seasons & 0.2845 & 1 & 0.2845 & 0.4611 & 4.8443 & $<0.05$ \\
\hline Stations & 1.5993 & 11 & 0.1454 & 0.2357 & 2.8179 & $<0.05$ \\
\hline Error & 6.7863 & 11 & 0.6169 & & & \\
\hline Total & 8.6701 & 23 & & & & \\
\hline
\end{tabular}

Table 9: The two-way ANOVA between the stations and seasons.

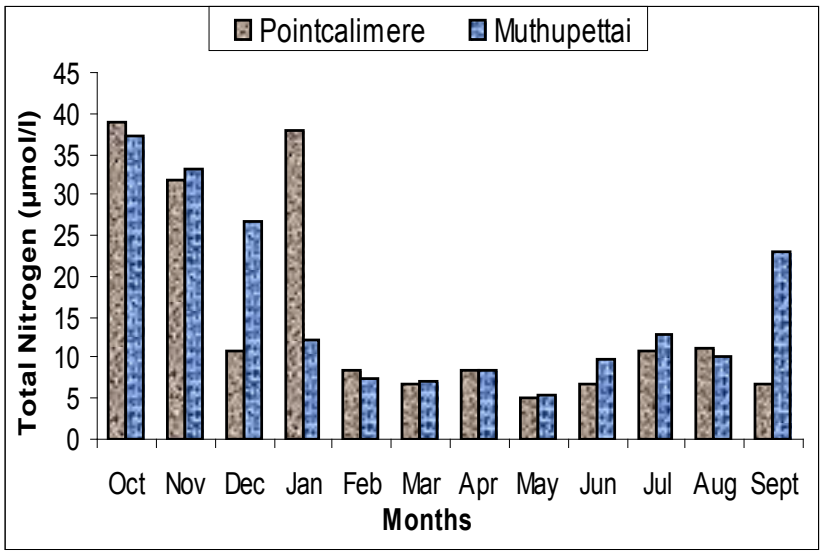

Figure 12: Monthly variations in Total nitrogen.

\begin{tabular}{|c|c|c|c|c|c|c|}
\hline Source of Variation & SS & $\boldsymbol{d f}$ & $\boldsymbol{M S}$ & $\boldsymbol{F}$ & $\boldsymbol{F}$ crit & $\boldsymbol{P}$-value \\
\hline Seasons & 4.4764 & 1 & 4.4764 & 0.0821 & 4.8443 & NS \\
\hline Stations & 2556.4333 & 11 & 232.4030 & 4.2628 & 2.8179 & NS \\
\hline Error & 599.7097 & 11 & 54.5191 & & & \\
\hline Total & 3160.6194 & 23 & & & & \\
\hline
\end{tabular}

Table 10: The two-way ANOVA between the stations and seasons.

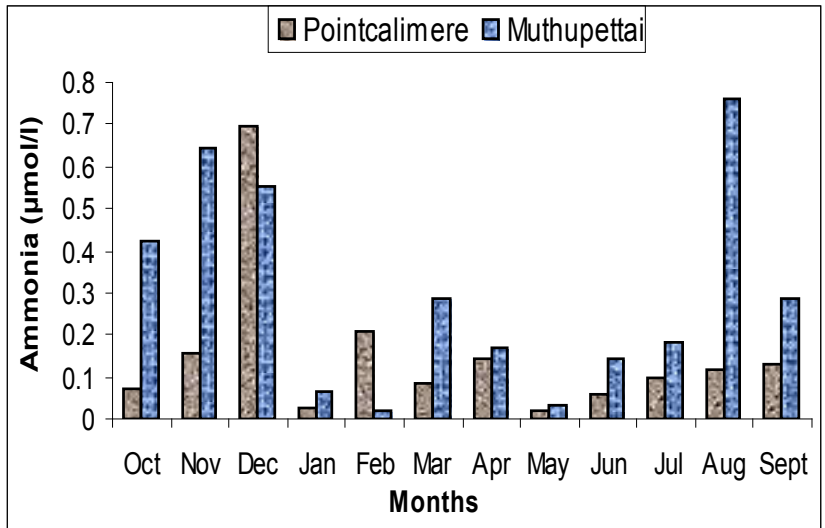

Figure 13: Monthly variations in ammonia.

\begin{tabular}{|c|c|c|c|c|c|c|}
\hline Source of Variation & SS & df & MS & F & F crit & P-value \\
\hline Seasons & 0.1263 & 1 & 0.1263 & 4.2521 & 4.8443 & NS \\
\hline Stations & 0.7048 & 11 & 0.0641 & 2.1571 & 2.8179 & NS \\
\hline Error & 0.3267 & 11 & 0.0297 & & & \\
\hline Total & 1.1578 & 23 & & & & \\
\hline
\end{tabular}

Table 11: The two-way ANOVA between the stations and seasons.

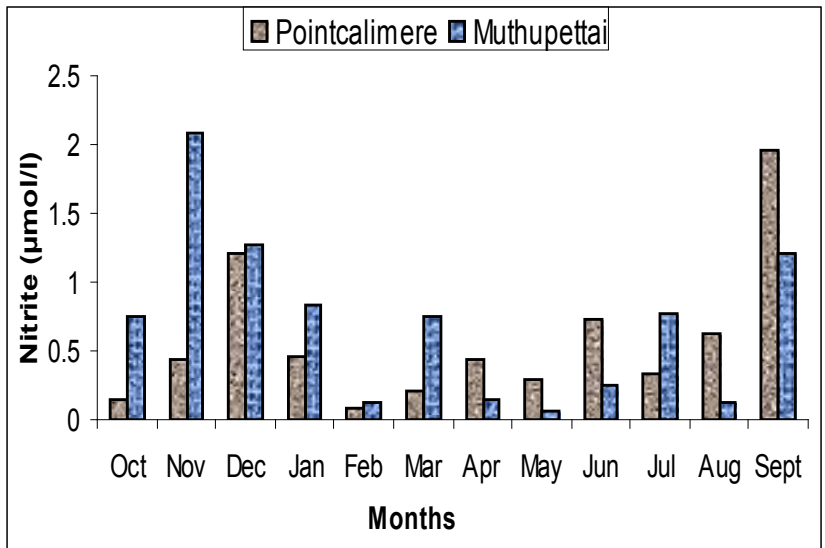

Figure 14: Monthly variations in nitrite.

\begin{tabular}{|c|c|c|c|c|c|c|}
\hline Source of Variation & SS & df & MS & F & F crit & P-value \\
\hline Seasons & 0.0862 & 1 & 0.0862 & 0.4004 & 4.8443 & $<0.05$ \\
\hline Stations & 4.8216 & 11 & 0.4383 & 2.0369 & 2.8179 & $<0.05$ \\
\hline Error & 2.3671 & 11 & 0.2152 & & & \\
\hline Total & 7.2749 & 23 & & & & \\
\hline
\end{tabular}

Table 12: The two-way ANOVA between the stations and seasons.

Nitrate: The nitrate at Point Calimere varied from $0.639 \mu \mathrm{mol} / \mathrm{l}$ to $7.088 \mu \mathrm{mol} / \mathrm{l}$ (Figure 15). Maximum $(7.088 \mu \mathrm{mol} / \mathrm{l})$ was recorded during monsoon (Dec. 2006). Minimum (0.639 $\mu \mathrm{mol} / \mathrm{l})$ was recorded during summer (May 2007). The nitrite at Muthupettai varied from $0.911 \mu \mathrm{mol} / \mathrm{l}$ to $7.675 \mu \mathrm{mol} / \mathrm{l}$ (Figure 15$)$. Maximum $(7.675 \mu \mathrm{mol} / \mathrm{l})$ was recorded during pre monsoon (Aug. 2006). Minimum $(0.911 \mu \mathrm{mol} / \mathrm{l})$ was recorded during post monsoon (Feb. 2007). The two-way ANOVA showed non-significant variations between the seasons and stations (Table 13). The dissolved oxygen values between the two stations are positively correlated $(r=0.926116 ; \mathrm{p}>0.001)$. 


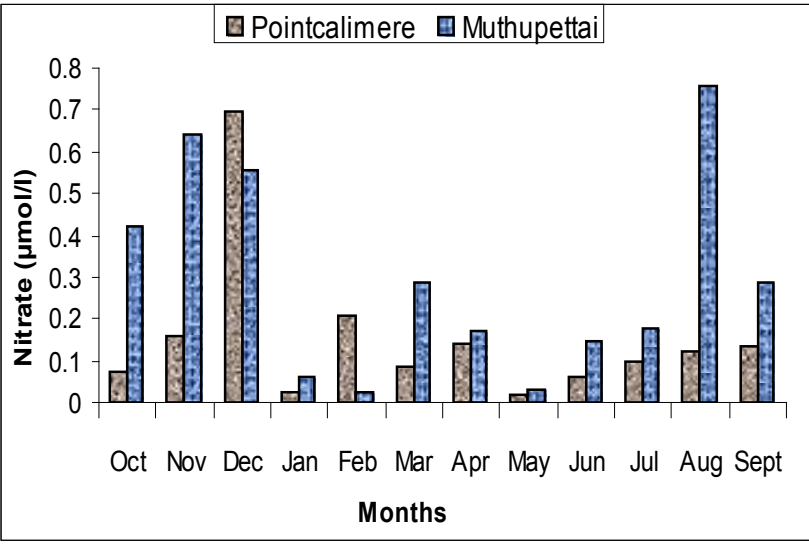

Figure 15: Monthly variations in nitrate.

\begin{tabular}{|c|c|c|c|c|c|c|}
\hline Source of Variation & SS & df & MS & F & F crit & P-value \\
\hline Seasons & 2.0028 & 1 & 2.0028 & 0.6667 & 4.8443 & NS \\
\hline Stations & 114.7987 & 11 & 10.4362 & 3.4743 & 2.8179 & NS \\
\hline Error & 33.0423 & 11 & 3.0038 & & & \\
\hline Total & 149.8437 & 23 & & & & \\
\hline
\end{tabular}

Table 13: The two-way ANOVA between the stations and seasons.

\section{Reactive Silicate}

The reactive silicate at Point Calimere varied from $16.163 \mu \mathrm{mol} / \mathrm{l}$ to $96.813 \mu \mathrm{mol} / \mathrm{l}$ (Figure 16). Maximum $(96.813 \mu \mathrm{mol} / \mathrm{l})$ was recorded during monsoon (Nov.2006). Minimum $(16.163 \mu \mathrm{mol} / \mathrm{l})$ was recorded during post monsoon (Mar. 2007). The reactive silicate at Muthupettai varied from $32.214 \mu \mathrm{mol} / \mathrm{l}$ to $102.210 \mu \mathrm{mol} / \mathrm{l}$ (Figure 16). Maximum $(102.210 \mu \mathrm{mol} / \mathrm{l})$ was recorded during monsoon (Oct.2006). Minimum (32.214 $\mu \mathrm{mol} / \mathrm{l}$ ) was recorded during summer (May 2007). The twoway ANOVA showed non-significant variations between the seasons and stations (Table 14). The dissolved oxygen values between the two stations are positively correlated $(\mathrm{r}=0.926116 ; \mathrm{p}>0.001)$.

\section{Discussion}

Adequate information on coastal wetlands such as estuaries, mudflats, coral reefs, mangroves etc., of Indian is available, and is having different characteristic behaviors in the physico-chemical and biological condition. Understanding such variations in the physicochemical aspects of these ecosystems will help understand the functioning of these fragile ecosystems and thereby help protecting not only the ecosystems but also the human population from water borne diseases. In general, the surface water temperature is influenced by sun shine; evaporation, cooled freshwater influx and admixture ebb flow from the adjoining neritic waters. Reid GK [13] remarked "The temperature of estuary, therefore, primarily is a function of temperature of the entering stream and the sea together with tidal states". The maximum surface water temperature of $30.4^{\circ} \mathrm{C}$ was recorded in the Muthupettai and minimum water temperature of $25.0^{\circ} \mathrm{C}$ was recorded at the Muthupettai. Kannan et al. [14] also reported minimum temperature values at shrimp pond drainage sites of Muthupettai mangrove environment. However, Sankar [15], Oswin and Rahman [16], Ajith et al. [17] have reported lower temperature from mangrove area. This might be due to their nature of study, which they have compared only Point Calimere and Muthupettai further outpouring by land runoff discharges from shrimp farms, wave action, wind action, fresh water discharge factors are governing light penetration capability estuarine waters. Considering the above fact turbidity of water column of mangrove environment may be the reason for the low surface water temperature in the mangrove sites of the Muthupettai.

The sediment temperature also showed similar trend as that of surface water temperature. In general, the surface water and sediment temperatures were lower than atmospheric temperature in two stations. This might be due to shallow $(0.5 \mathrm{~m})$ nature of the environment, while the minimum temperature of $21.00^{\circ} \mathrm{C}$ was recorded at Point Calimere. This might be due to higher average of the station $(5.0 \mathrm{~m})$.

Salinity is one of the important key factors which determine the composition of biological component in the marine environment. The fluctuations in salinity affect the biological characteristics of the environment. Paramasivam and Kannan [18] Stated that the salinity at any point in an estuary will be depended on the topography of the estuary, the state of tide (high or low, and spring or neap), the time of the year controlling rainfall etc., and the extent of freshwaters flow. Present study was recorded high salinity values could be attributed to the high degree of evaporation and also due to neritic water dominance from sea. The lower salinity values of $24.0 \mathrm{ppt}$ were recorded in the Muthupettai might be due to the continuous inflow of freshwater into the estuary through the six rivers (Branchlets of Cauvery River) during this part of the year. Paramasivam and Kannan [18] have recorded 2-29.5 ppt.

The water $\mathrm{pH}$ recorded during the present study fluctuated in alkaline range with low range of 7.2 at Point Calimere and the maximum of 8.5 were recorded in Point Calimere. The uptake of $\mathrm{CO}_{2}$ by the photosynthetic organisms especially phytoplankton in the Muthupettai and Point Calimere waters could have increased the $\mathrm{pH}$ levels. Similar range of $\mathrm{pH}$ has also been reported by earlier researchers from this study area $[15,16,18]$. Knowledge of nutrients, pertaining to their contributory sources, utilization levels, mechanism and rates of their release will be of great value to assess the productivity of an estuary. There are several instants to show that river contribute nutrients in a significant measure to the estuary and there are also

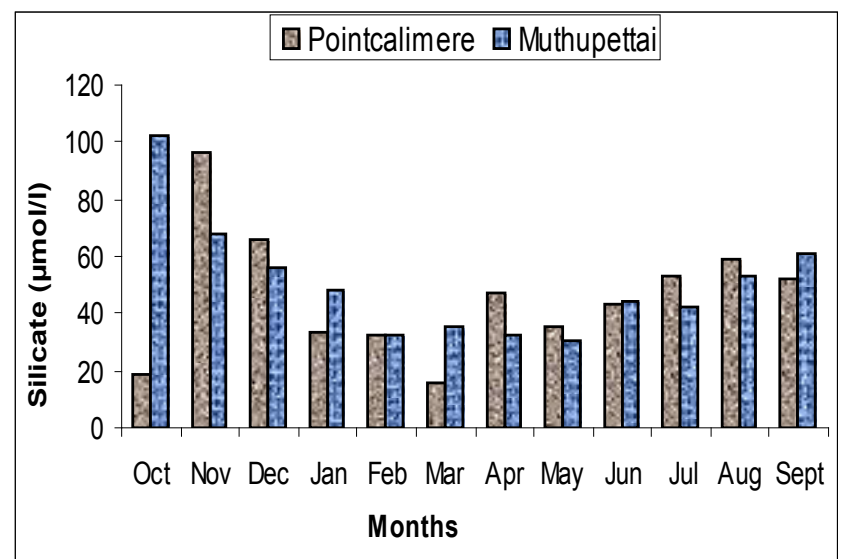

Figure 16: Monthly variations in silicate.

\begin{tabular}{|c|c|c|c|c|c|c|}
\hline Source of Variation & SS & df & MS & F & F crit & P-value \\
\hline Seasons & 119.4656 & 1 & 119.4656 & 0.3018 & 4.8443 & NS \\
\hline Stations & 5497.4244 & 11 & 499.7659 & 1.2627 & 2.8179 & NS \\
\hline Error & 4353.8635 & 11 & 395.8058 & & & \\
\hline Total & 9970.7535 & 23 & & & & \\
\hline
\end{tabular}

Table 14: The two-way ANOVA between the stations and seasons. 
number of instances to point out that the contribution is more from neritic end.

Nutrients are considered as one of the most important parameters in the marine environment. The distribution of nutrients is mainly based on the season's tidal conditions and river flow. Silicate is different from nitrogen and phosphate in some ways and in the strictest sense it is not considered as a nutrient but its usefulness in the formation of skeleton of diatoms and radiolarians is very high. The concentration of reactive silicate was found to be much higher than other nutrients. In the present study, lower silicate values $32.214 \mu \mathrm{mol} / \mathrm{l}$ was recorded from the Muthupettai, while high values $102.210 \mu \mathrm{mol} / \mathrm{l}$ of the silicate observed in Point Calimere. This can be attributed to the influx aquaculture water during water exchange with silicate. However, Kannan et al. [14] reported a lower range of silicate (0.6 to $21.72 \mu \mathrm{mol} / \mathrm{l})$ from this environment. Paramasivam and Kannan [18] have reported even more silicate level upto $(115.632 \mu \mathrm{mol} / \mathrm{l})$ from this mangrove environment. High concentration of Ammonia $0.544 \mu \mathrm{mol} / \mathrm{l}$ was observed in Muthupettai and less concentration of Ammonia 0.030 $\mu \mathrm{mol} / \mathrm{l}$ was observed in Point Calimere. Further, the decomposition of plankton also contributed to the higher concentration of Ammonia $[19,20]$.

The higher phosphate value $0.821 \mu \mathrm{mol} / \mathrm{l}$ was recorded from Muthupettai might be influenced by the freshwater inflow and lower value $(0.670 \mu \mathrm{mol} / \mathrm{l})$ from the open sea might be due to utilization of phytoplankton. Nair et al. [21] have opined that the demised river discharge and utilization for biological productivity also cause low phosphate in the environment. However, the present range of phosphate level is very low when compared to Physico-chemical characteristics of Muthupettai mangrove Environment [14,18].

Nitrite concentration was recorded during the present study showed optimum values at all the two stations. Nitrite concentration was found to be much lower than that of nitrate; however the same trend of fluctuation was noticed in both the cases during the present study. Maximum $(1.957 \mu \mathrm{mol} / \mathrm{l})$ was recorded at Point Calimere and minimum concentration $(0.082 \mu \mathrm{mol} / \mathrm{l})$ was recorded at Point Calimere. The decomposition of phytoplankton, reduction of nitrate and oxidation of ammonia combined together or individually contribute to the concentration of nitrite in the environment $[22,23]$. However earlier reports $[15,17,18]$ found even higher concentration of nitrite from this mangrove environment.

Higher concentration of nitrate could be possible due to heavy rainfall, land drainage and agricultural discharge. Anbazhagan [22] suggested that the addition of nitrogenous nutrients mainly through freshwater and terrestrial runoff in the lagoon definitely increased the level of nitrate. Lower concentration of nitrate was recorded at open sea may be due to utilization of nitrate by the benthic algae and phytoplankton. High rainfall in forests $[14,18,23]$ have reported higher concentration of nitrate $(0.12-14.17 ; 0.15-14.17 ; 0.96-6.90 ; \mu \mathrm{mol} / \mathrm{l}$ respectively) from this mangrove environment.

Total Nitrogen concentration was maximum $38.916 \mu \mathrm{mol} / \mathrm{l}$ at Point Calimere and the same region minimum value were recorded 5.123 $\mu \mathrm{mol} / \mathrm{l}[14]$ recorded the same value in Muthupettai mangroves and [11] also recorded comparable value of total nitrogen in Pitchavaram mangroves. Here it can conclude that, the physical and chemical properties of marine ecosystems are representative of the climatic and pollution conditions, sewage basin and biological formation.
The surface water is decided entirely by ecological variations that can determine the selection of species and there species metabolic rate, physiological performance, abundance, species composition and stability. In the two different sampling stations is directly or indirectly it can polluted. Sewage and manmade activities is a major problem of species and effect of habitat loss, overharvesting and anthropogenic activities is a greatest effect on diversity of species. Therefore, study were advised from coastal related polluted activities and the wastes from various sources should be avoid enter from coastal regions and treated properly before released into the marine environment.

\section{References}

1. Balasubramaniam TS (2000) Modifications of craft and gear in diversified tuna fishery undertaken at Tharuvaikulam, Gulf of Mannar, India. Mar Fish Infor Serv T\&E Ser No 164: 19-24.

2. Kathiresan K, Rajendran N, Thangadurai G (1996) Growth of a mangrove seedling in the intertidal area of Vellar estuary, Southeast coast of India. Indian J Mar Sci 25: 240-243.

3. Menon NN, Balchand AN, Menon NR (2000) Hydrobiology of the Cochin backwater System-A review. Hydrobiol 430: 149-183.

4. Rajendran N (1997) Studies on mangrove associated prawn seed resources of the Pitchavaram, Southeast coast of India. Annamalai University, India.

5. Kathiresan K (2000) A review of studies on Pichavaram mangroves, South east coast of India. Hydrobiol 430: 185-205.

6. Ghosh TK, Patil MM, Thakur SG (1996) Mangrove vegitations around Dahanu creek Region-A case study. Ecol 11: 17-22.

7. Banerjee V, Choudhury PKR (1987) Preliminary studies on artificial regeneration of mangrove forests in the Sundarbans, West Bengal. The Indian For 112: 203- 222

8. Das AB, Basak UC, Das P (2002) Karyotype diversity in three species of Heritiera, a common mangrove tree on the Orissa coast. Cytobios 80: 321 71-78.

9. Rao BK, Swamy ASR (1991) Sediment characteristics of environments in the modern Krishna Godavari deltas. In: R. Vaidyanathan (1991) Quaternary Deltas of India. Geological Society of India. Bangalore, India.

10. Kannan L, Vasantha K (1992) Microphytoplankton of the Pitchavaram mangals, southeast coast of India: species composition and population density. Hydrobiologia 247: 77-86.

11. Kathiresan K, Ravikumar S (1993) Two endangered species of mangrove in Pichavaram. The Indian For 119: 773.

12. Strickland JDH, Parsons TR (1972) A practical hand book of seawater analysis Bull Fish Res Bd Canada p 167.

13. Reid GK (1961) Ecology of inland waters and estuaries. Reinhold Publishing Corporation, New York 375

14. Kannan L, Paramasivam S, Seenivasan R, Nadimuthu N (2003) Impact of shrimp farm activities on the water quality of Muthupettai mangrove environment, Southeast coast of India. In: Recent trends in Hydrogeochemistry, Ramanathan. A.L. and R.Ramesh (2003) Capital Publishing Company, New Delhi, India.

15. Sankar G (1998) Studies on the hydrobiology, benthic ecology and fisheries of Muthupet lagoon. Ph.D Thesis, Annamalai University, India.

16. Oswin D, Rahman AA (1997) Impact of aquaculture effluents on mangroves. In: R. Santhanam, V. Ramadhas and P. Gopalakrishna (1997). Proc Nat Sem Water Qua Iss Aquacult Sys.

17. Ajith kumar TT, Thangaradjou T, Kannan L (2006) Physico-chemical and biological properties of the Muthupettai mangroves in Tamil Nadu. J Mar Bio Ass India 48: 131-138.

18. Paramasivam S, Kannan L (2005) Physico-chemical characteristics of Muthupettai mangrove Environment, Southeast coast of India. Inter J Ecol Environ Sci 31: 273-278

19. Saraladevi K, Sankaranarayanan VN, Venugopal P (1991) Distribution of nutrients in the Periyar river estuary. Indian J Mar Sci 20: 49-54. 
Citation: Srilatha G, Varadharajan D, Chamundeeswari K, Mayavu P (2013) Study on Physico-Chemical Parameters in Different Mangrove Regions, Southeast Coast of India. J Environ Anal Toxicol 3: 182. doi:10.4172/2161-0525.1000182

Page 8 of 8

20. Ananathan G (1995) Plankton ecology and heavy metal studies in the marine environs of Pondicherry, India. Annamalai University, India.

21. Nair NB, Aziz PK, Dharmaraj K, Arunachalam M, Krishnakumar K et al. (1983) Ecology of Indian estuaries. V. Primary Productivity of the Ashtamudi estuary, Southwest coast of India. Proc Indian Aca Sci 93:9-23.
22. Anbazhagan P (1988) Hydrobiology and benthic ecology of Kodiyakarai coastal sanctuary (South east coast of India). Annamalai University, India.

23. Ewel C, Katherine, Songfa Z, Pinzon, Zulelka S, John EA (1998) Environmental effects of Canopy gap formation in high rainfall mangrove forests. Biotropica 30: 510-518. 